\title{
Erratum: Vascular calcification in patients with type 2 diabetes: the involvement of matrix Gla protein
}

Sophie Liabeuf ${ }^{1,2^{*}}$, Olivier Bourron ${ }^{3}$, Cees Vemeer ${ }^{4}$, Elke Theuwissen ${ }^{4}$, Elke Magdeleyns ${ }^{4}$, Carole Elodie Aubert ${ }^{3}$, Michel Brazier ${ }^{1}$, Romuald Mentaverri ${ }^{1}$, Agnes Hartemann ${ }^{3}$ and Ziad A Massy ${ }^{1,5}$

\section{Corrections}

Following publication of our article [1], it has come to our attention that Olivier Bourron's name was displayed incorrectly. We publish this correction to update the author list, which is as follows:

Sophie Liabeuf ${ }^{1,2}$, Olivier Bourron ${ }^{3}$, Cees Vemeer ${ }^{4}$, Elke Theuwissen ${ }^{4}$, Elke Magdeleyns ${ }^{4}$, Carole Elodie Aubert ${ }^{3}$, Michel Brazier ${ }^{1}$, Romuald Mentaverri ${ }^{1}$, Agnes Hartemann ${ }^{3}$, and Ziad A. Massy ${ }^{1,5}$

We apologize for any inconvenience this has caused.

\begin{abstract}
Author details
'INSERM U1088, Jules Verne University of Picardy, F-80000 Amiens, France.

${ }^{2}$ Clinical Research Centre, Division of Clinical Pharmacology, Amiens University Hospital and the Jules Verne University of Picardy, F-80000 Amiens, France. ${ }^{3}$ Diabetology Department, AP-HP, Pitie-Salpétrière Hospital and Pierre and Marie Curie University of Paris, F-75005 Paris, France. ${ }^{4}$ VitaK, Maastricht University, Maastricht, The Netherlands. ${ }^{5}$ Division of Nephrology, Ambroise Paré Hospital, F-92104 Boulogne-Billancourt, France.
\end{abstract}

Received: 19 December 2014 Accepted: 19 December 2014

Published online: 24 January 2015

\section{Reference}

1. Liabeuf S, Olivier B, Vemeer C, Theuwissen E, Magdeleyns E, Aubert CE, et al. Vascular calcification in patients with type 2 diabetes: the involvement of matrix Gla protein. Cardiovasc Diabetol. 2014;13:85

\footnotetext{
*Correspondence: liabeuf.sophie@chu-amiens.fr 'INSERM U1088, Jules Verne University of Picardy, F-80000 Amiens, France ${ }^{2}$ Clinical Research Centre, Division of Clinical Pharmacology, Amiens University Hospital and the Jules Verne University of Picardy, F-80000 Amiens, France
}

\author{
Submit your next manuscript to BioMed Central \\ and take full advantage of: \\ - Convenient online submission \\ - Thorough peer review \\ - No space constraints or color figure charges \\ - Immediate publication on acceptance \\ - Inclusion in PubMed, CAS, Scopus and Google Scholar \\ - Research which is freely available for redistribution
}

Submit your manuscript at www.biomedcentral.com/submit 